\title{
Depositional rates in the Ediacaran \\ Nafun Group, Oman, and the wider late Proterozoic world
}

\author{
MARJORIE D. CANTINE ${ }^{1}$, ALAN ROONEY ${ }^{2}$, ANDY \\ KNOLL $^{3}$ AND KRISTIN BERGMANN ${ }^{1}$
}

${ }^{1}$ Massachusetts Institute of Technology

${ }^{2}$ Yale University

${ }^{3}$ Harvard University

Presenting Author: mcantine@mit.edu

The depositional rates of sedimentary strata reflect fundamental controls on Earth surface systems, including accommodation space, sediment supply, and, in the case of chemical sediments, water chemistry. The rate at which sediments are deposited and buried in the ocean exerts a key control on their diagenetic history and on biogeochemical cycling within sediments.

Interpreting and comparing depositional rates across locations and successions is challenging because the apparent depositional rate of a sedimentary package scales inversely with the length of time it spans (the Sadler Effect). This study leverages new Re-Os isochron-derived dates for the Ediacaran Nafun Group of Oman to determine depositional rates. These dates indicate an increase in sedimentary thickness and depositional rate in the late Ediacaran Period not wholly explained by the Sadler Effect.

To see if this trend holds globally, 400+ depositional rates within globally distributed Ediacaran successions are tabulated. In some cases, high apparent depositional rates are best understood as a result of the Sadler Effect. Yet in some locations in Western Gondwana record much thicker sedimentary packages and higher depositional rates in the second half of the Ediacaran Period, consistent with regional tectonic control on sedimentation and depositional rate. These successions contain thick deposits of carbonate, suggesting that ocean chemistry also played a role in generating these voluminous latest Proterozoic successions.

Noting thick deposits of carbonate strata near the ProterozoicCambrian boundary in a few Ediacaran (635-541 Ma) successions, some workers (e.g., Wood et al. 2017) have suggested that these thick carbonate successions reflect rapid depositional rates resulting from highly oversaturated seawater, contemporaneous with the first appearance of carbonatebiomineralizing metazoans. We discuss the implications of depositional rate for reconstructing ocean chemistry, interpreting paleoredox records, and tracking change in Earth's surface environments in space and time. 